\title{
Life and Death of Podocytes: Not Only a Matter of Vascular Endothelial Growth Factor
}

\author{
Rubina Novelli Ariela Benigni \\ IRCCS - Istituto di Ricerche Farmacologiche Mario Negri, Centro Anna Maria Astori, Science and \\ Technology Park Kilometro Rosso, Bergamo, Italy
}

Renovascular disease (RVD) comprises a variety of conditions that alter the arterial supply of the kidney, inducing hypertension and affecting renal function, ultimately leading to chronic kidney disease. Although renal artery interventions are frequent therapeutic strategies for treating RVD, many patients derive little net benefit from them. This creates an urgent need for the identification of disease mediators that could be targeted to prevent irreversible injury in the post-stenotic kidney or other complications.

Soon after its discovery, endothelin-1 (ET-1) was identified as a key factor in controlling kidney function and promoting renal disease progression [1], due to its vasoconstrictive action and mitogenic property. More recently, the role of ET-1 in fostering renal injury in chronic RVD was put forward, with a particular focus on the roles of ET receptors, ET-1 type $\mathrm{A}\left(\mathrm{ET}_{\mathrm{A}}\right)$ and $\mathrm{ET}-1$ type $\mathrm{B}\left(\mathrm{ET}_{\mathrm{B}}\right)$ $[2,3]$. Results from these studies documented the disparate effects of the selective antagonism of $\mathrm{ET}_{\mathrm{A}}$ receptor compared to dual $\mathrm{ET}_{\mathrm{A}} / \mathrm{ET}_{\mathrm{B}}$ [3] or $\mathrm{ET}_{\mathrm{B}}$ receptor [2] blockade in a porcine model of chronic $\mathrm{RVD}$. While $\mathrm{ET}_{\mathrm{A}}$ receptor antagonist improved hypertension, microvascular rarefaction and renal injury, dual $\mathrm{ET}_{\mathrm{A}} / \mathrm{ET}_{\mathrm{B}}$ blunted the therapeutic effects, and single $\mathrm{ET}_{\mathrm{B}}$ receptor inhibition was ineffective.

In the current issue of the American Journal of $\mathrm{Ne}$ phrology, Harvey et al. further investigated the involve-

\section{KARGER}

E-Mail karger@karger.com

www.karger.com/ajn ment of the ET-1 pathway in chronic RVD, examining the effects of the $\mathrm{ET}_{\mathrm{A}}$ and $\mathrm{ET}_{\mathrm{B}}$ receptor antagonism on podocyte integrity and survival in the ischemic kidney [4]. Podocytes are highly specialized epithelial cells constituting the outer layer of the glomerular filtration barrier, and their dysfunction and loss are hallmarks of proteinuric renal disease [5]. Notably, podocytes possess a fully functional ET system, and evidence has highlighted the role of ET-1 in promoting structural and functional alteration of these cells in renal disease [5]. Mindful of the previously reported in vivo effects of ET-1 blockade, in the present work, the authors exploited a hypoxic in vitro approach that offered the opportunity to dissect the mechanisms underlying podocyte injury and recovery by mimicking the renal environment of chronic RVD. They analysed human podocytes that were exposed to chronic hypoxia and treated with either an $\mathrm{ET}_{\mathrm{A}}$ or $\mathrm{ET}_{\mathrm{B}}$ receptor antagonist. Hypoxia decreased the podocyte count, while it increased the number of cells displaying morphological changes suggestive of apoptosis, such as nuclear condensation and fragmentation. These effects paralleled the decreased expression of vascular endothelial growth factor (VEGF) and slit diaphragm-associated proteins podocin and nephrin. Furthermore, hypoxic podocytes displayed increased expression of the anti-VEGF soluble receptor s-Flt 1 and of pro-apoptotic mediators, including BAX, p53 and SMAC. Treatment with $\mathrm{ET}_{\mathrm{A}}$ receptor antagonist (c) 2016 S. Karger AG, Basel

0250-8095/16/0432-0071\$39.50/0
Ariela Benigni, $\mathrm{PhD}$

IRCCS - Istituto di Ricerche Farmacologiche Mario Negri Centro Anna Maria Astori, Science and Technology Park Kilometro Rosso Via Stezzano, 87, IT-24126 Bergamo (Italy)

E-Mail ariela.benigni@marionegri.it 
significantly improved podocyte survival, preserved VEGF production and attenuated apoptotic factor expression, promoting instead a pro-survival expression profile with the upregulation of $\mathrm{p}$-akt and Bcl-2. These effects were not observed after $\mathrm{ET}_{\mathrm{B}}$ blockade, which conversely was harmful to hypoxic podocytes by inducing an increased s-Flt 1 secretion in the cell medium.

The first finding of this study is the beneficial effect of $\mathrm{ET}_{\mathrm{A}}$ - not shared by $\mathrm{ET}_{\mathrm{B}}$ - receptor antagonist on hypoxic podocytes. Although it is well known that ET-1 favours renal disease progression via the detrimental action of the peptide on podocytes, it is still a matter of debate whether selective $\mathrm{ET}_{\mathrm{A}}$ receptor over $\mathrm{ET}_{\mathrm{A}} / \mathrm{ET}_{\mathrm{B}}$ receptor blockade should be preferred for the treatment of kidney diseases. In an aging-associated glomerulosclerosis model, the $\mathrm{ET}_{\mathrm{A}}$ selective antagonism was more effective than non-selective $\mathrm{ET}_{\mathrm{A}} / \mathrm{ET}_{\mathrm{B}}$ receptor blockade in reversing glomerulosclerosis and attenuating podocyte structural damage [6]. Moreover, selective $\mathrm{ET}_{\mathrm{A}}$ receptor and nonselective $\mathrm{ET}_{\mathrm{A}} / \mathrm{ET}_{\mathrm{B}}$ receptor blockades reduced both albuminuria and glomerular permeability in a model of diabetic nephropathy, but only selective $\mathrm{ET}_{\mathrm{A}}$ receptor blockade restored nephrin and podocin expression and decreased glomerular inflammation [7]. By contrast, results from transgenic mice indicated that podocyte-specific deletion of both $\mathrm{ET}_{\mathrm{A}}$ and $\mathrm{ET}_{\mathrm{B}}$ receptors was protective in diabetic mice, offering the rationale for hypothesizing that dual $\mathrm{ET}_{\mathrm{A}} / \mathrm{ET}_{\mathrm{B}}$ is more beneficial than single $\mathrm{ET}_{\mathrm{A}}$ antagonism [8]. In such a controversial context, the new findings by Harvey et al. add support to the use of selective over non-selective ET-1 receptor blockade for the treatment of chronic RVD.

The second significant finding of this study relates to the mechanism underlying the $\mathrm{ET}_{\mathrm{A}}$ antagonist-mediated podocyte protection. Taking advantage of the use of VEGF neutralizing antibodies, Harvey et al. identified VEGF as a pivotal factor for podocyte protection mediated by the $\mathrm{ET}_{\mathrm{A}}$ receptor blockade, and proposed VEGF's scarce bioavailability as a potential explanation for the detrimental effects of single $\mathrm{ET}_{\mathrm{B}}$ receptor inhibition [4]. Podocytes are both the source and target of glomerular VEGF, which is essential for maintaining the normal podocyte function and phenotype. Among these, an elegant study by Eremina et al. [9] clearly demonstrated the protective role of podocyte-produced VEGF in the pathogenesis of renal thrombotic microangiopathy, indicating the importance of preserving podocyte VEGF production for maintaining glomerular filtration barrier health and function. The ability of $\mathrm{ET}_{\mathrm{A}}$ antagonist to affect VEGF production was previously described in animal models of diabetes, but was confined only to the heart. In type I diabetes, the administration of $\mathrm{ET}_{\mathrm{A}}$ antagonist normalized the downregulated levels of VEGF, and this paralleled the recovery of cardiac contraction [10], while in a model of type II diabetes, a significant induction of myocardial VEGF expression was obtained after $\mathrm{ET}_{\mathrm{A}}$ antagonism treatment, and was associated with the restoration of the heart's capillary network [11]. Harvey et al. have now provided the first piece of evidence that $\mathrm{ET}_{\mathrm{A}}$ antagonism can have a direct effect on glomerular podocytes through VEGF.

The in vitro approach of this study would represent a potential limitation to its clinical applicability. To this end, additional in vivo investigation is warranted to confirm that $\mathrm{ET}_{\mathrm{A}}$ antagonism-mediated podocyte protection is due to VEGF. The unprecedented role of VEGF in mediating the protective effect of $\mathrm{ET}_{\mathrm{A}}$ antagonism on hypoxic podocytes proposed by Harvey et al. makes it possible to envision the $\mathrm{ET}_{\mathrm{A}}$ receptor/VEGF pathway involvement in other renal diseases characterized by oxidative stress and fibrosis, such as diabetes. Notably, in experimental diabetic nephropathy, a number of studies documented the synergistic renoprotective effect exerted by the association of $\mathrm{ET}_{\mathrm{A}}$ receptor antagonism with angiotensin-converting enzyme inhibitors (ACEi) [11, 12]. Such positive preclinical results provided the rationale for current trials in patients. Thus, the investigation of whether the effects of combined $\mathrm{ACEi}-\mathrm{ET}_{\mathrm{A}}$ receptor antagonism treatment are related to VEGF production in patients in ongoing trials could be an intriguing way forward.

\section{Disclosure Statement}

The authors have no conflict of interest to declare.

\section{References}

1 Benigni A, Perico N, Gaspari F, Zoja C, Bellizzi L, Gabanelli M, Remuzzi G: Increased renal endothelin production in rats with reduced renal mass. Am J Physiol 1991;260(3 pt 2):F331-F339.

2 Chade AR, Stewart NJ, Peavy PR: Disparate effects of single endothelin-A and -B receptor blocker therapy on the progression of renal injury in advanced renovascular disease. Kidney Int 2014;85:833-844.

3 Chade AR, Tullos N, Stewart NJ, Surles B: Endothelin-A receptor antagonism after renal angioplasty enhances renal recovery in renovascular disease. J Am Soc Nephrol 2015;26: 1071-1080.
72

Am J Nephrol 2016;43:71-73

DOI: $10.1159 / 000444723$
Novelli/Benigni 
4 Harvey T, Engel J, Chade AR: VEGF and podocyte protection in chronic hypoxia: effects of endothelin-A receptor antagonism. Am J Nephrol 2016;43:74-84.

5 Barton M, Tharaux PL: Endothelin and the podocyte. Clin Kidney J 2012;5:17-27.

6 Ortmann J, Amann K, Brandes RP, Kretzler M, Münter K, Parekh N, Traupe T, Lange M, Lattmann T, Barton M: Role of podocytes for reversal of glomerulosclerosis and proteinuria in the aging kidney after endothelin inhibition. Hypertension 2004;44:974-981.

7 Saleh MA, Pollock JS, Pollock DM: Distinct actions of endothelin A-selective versus combined endothelin $\mathrm{A} / \mathrm{B}$ receptor antagonists in early diabetic kidney disease. J Pharmacol Exp Ther 2011;338:263-270.
8 Lenoir O, Milon M, Virsolvy A, Hénique C, Schmitt A, Massé JM, Kotelevtsev Y, Yanagisawa M, Webb DJ, Richard S, Tharaux PL: Direct action of endothelin-1 on podocytes promotes diabetic glomerulosclerosis. J Am Soc Nephrol 2014;25:1050-1062.

9 Eremina V, Jefferson JA, Kowalewska J, Hochster H, Haas M, Weisstuch J, Richardson C, Kopp JB, Kabir MG, Backx PH, Gerber HP, Ferrara N, Barisoni L, Alpers CE, Quaggin SE: VEGF inhibition and renal thrombotic microangiopathy. N Engl J Med 2008;358: 1129-1136.

10 Jesmin S, Miyauchi T, Goto K, Yamaguchi I: Down-regulated VEGF expression in the diabetic heart is normalized by an endothelin eta receptor antagonist. Eur J Pharmacol 2006; 542:184-185.
11 Zoja C, Cattaneo S, Fiordaliso F, Lionetti V, Zambelli V, Salio M, Corna D, Pagani C, Rottoli D, Bisighini C, Remuzzi G, Benigni A: Distinct cardiac and renal effects of ETA receptor antagonist and ace inhibitor in experimental type 2 diabetes. Am J Physiol Renal Physiol 2011;301:F1114-F1123.

12 Gagliardini E, Corna D, Zoja C, Sangalli F, Carrara F, Rossi M, Conti S, Rottoli D, Longaretti L, Remuzzi A, Remuzzi G, Benigni A: Unlike each drug alone, lisinopril if combined with avosentan promotes regression of renal lesions in experimental diabetes. Am J Physiol Renal Physiol 2009;297:F1448F1456. 